\title{
ケテンジチオアセタール誘導体の農薬への 応用に関する研究
}

\author{
谷中 国 昭 \\ 日本農薬化学研究所
}

\section{Studies on the Application of Ketene Dithioacetals to Pesticides}

\author{
Kuniaki TANINAKA \\ Chemical Research Laboratories, Nihon Nohyaku Co., Ltd., \\ Nishiyodogawa-ku, Osaka 555, Japan
}

During the studies on the application of organic sulfur compounds to agricultural fungicides, some of ketene dithioacetals (III) were found to be effective for rice blast control. In order to prepare III, the reaction of carbon disulfide with active methylene compounds was investigated and a large number of related compounds were synthesized.

In those, one of the most potent compounds, isoprothiolane (5b, diisopropyl 1,3-dithiolan-2ylidenemalonate) is now used practically as a systemic fungicide to control rice blast disease.

The structure-activity relationships of isoprothiolane analogs against rice blast were studied and summarized as follows.

Of the compounds with ring structure (4), only 1,3-dithiolanes showed high effect and systemic property. Those without ring structure (3) were lacked in systemic and persistent properties, though some of them showed strong fungicidal activity. Double bond and two sulfur atoms were necessary. That was to say, ketene dithioacetal structure in isoprothiolane was essential for rice blast control. The optimum size of alkyl groups in 5 seemed to be $\mathrm{C}_{2}-\mathrm{C}_{5}$ alkyl with 48 total carbon number. Thioester or amide analogs $(\mathbf{2 0}, \mathbf{2 1})$ were less active than the corresponding ester compounds.

An interesting property of isoprothiolane against planthopper was observed from the field tests on rice blast. That was the remarkable suppression of population density of planthoppers in the field. This discovery implies the importance of close observation to evaluate biological activities.

As one of another biological activity of III, strong fungicidal property against rice sheath blight was found in some compounds having 4-chloromethyl-1,3-dithiolane moiety.

\section{は じめに}

有機イオウ化合物は，合成農薬の中で大きな分野を占 めているたとえば農薬ハンドブッグには，農薬成分 として 244 種の有機化合物が記載されており，その内で 構成元素としてイオウを含むるのは 89 種に打よび，こ れらの化合物では, イオウ原子の存在が直接, 間接的に その生物活性発現の場で, 重要な役割を演じていること
が明らかにされている2).

とくに, 植物体内への浸透性, 植物体内での活性化, 効力の持続性, 対象生物への選択性等の場面でイオウが 関与する種々の重要な役割は, 活性発現の機構を考察し, 新しい生物活性物質を設計してゆく面からも注目に值す る.

著者らは，合成イモ千薬の非水銀化が，有機塩素剛や 有機リン郕の発見によって達成されたあとで, この両者 
以外の系統の化合物から，これらを凌駕する新しいイモ チ薬を見いだすため，有機イオウ化合物に着目し，その 農薬への応用を研究してきた。

新農薬イソプロチオラン (フジワン®) は, この研究 で，著者らが見いだしたイオウを含む，新規な化学構造 の浸透性イモチ病防除薬である ${ }^{3)}$. 本稿ではイソプロチ オランの母体となったケテンジオアセタール系化合物の 合成や生物活性，構造と活性の関係について解説する。

\section{ケテンジオアセタール類の合成}

イオウを含を有機化合物を合成する場合，イオウ原子 を構造中に組み込む方法として, 硫化水素や単体イオウ から工業的に得られる含イオウ有機合成試剤を利用し， 有機合成化学的手法で目的化合物に導くのが常法であ る、二硫化炭素は，このような試用として有用であり， 有機イオウ化合物合成の出発物質として，その反応性は 多様で, 興味ある研究対像の一分野である ${ }^{4,5)}$. 著者ら も, 二硫化炭素から得られる既知, 未知の多数の化合物 を合成し，その生物活性を検討した。 そして，Fig. 1 に示した ethyl 2-carbethoxy-3, 3-bis(methylmercapto)acrylate (3a) がイモチに対し，イモチ菌接種後の散布 (治療効果試験) でかなりの活性を示すことを見いだし

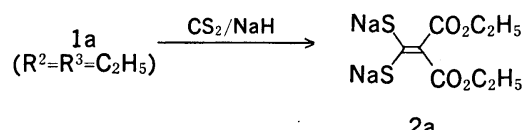

Fig. 1

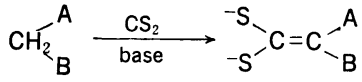

( I )
(II)

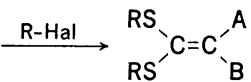

(III)
Fig. 2

た ${ }^{6 \sim 8)}$. この発見を契機に，著者らは 二硫化炭素と活性メチレン化合物, と くにマロン酸エステルとの反応につい て合成化学的な研究を開始した。

活性メチレン化合物（I）と二硫化 炭素から得られるジアニオン（II）を アルキル化し，ケテンジチオアセター ル類を合成する方法はよく知られた反 応であるが99, III 類の合成と，その 複素環化合物合成への有用性が注目さ れ，多様で興味ある研究対象となった のは比較的近年である ${ }^{10)}$. 対象として 研究された活性メチレン化合物は限ら
れておりこれらに関しては F. C. V. Larsson らの報 告に詳しく引用されている11)。

とくにマロン酸エステルを対象にした研究は, 1944 年 の P. V. Laakso の仕事 ${ }^{12}$ が最も古く，3a の合成法も 記載されている．著者らが $3 a$ のイモチに対する活性を 見いだした当時，この反応に関しては，彼らが明らかに した以上の知見は得られていなかった。またこの系統の 誘導体についても，わずかに 4 化合物の合成例が報告さ れていたのみであった ${ }^{12 \sim 15)}$. その後 K. A. Jensen ${ }^{16)} ら$

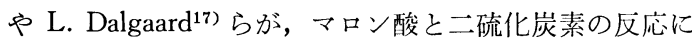
ついて詳しい研究と，新しい誘導体を報告している.

マロン酸エステルも含め, 一般に活性メチレンと二硫 化炭素の反応では, 塩基の種類と反応溶媒に関して, 種 々の検討がなされてきた．多くの場合不活性溶媒中で金 属アルカリや八イドライド類で, 活性メチレンのカルバ ニオンを生成させ，二硫化炭素を反応させる方法が採用 されてきた ${ }^{9}$. アルコール等の二硫化炭素に対して活性 を示す溶媒の場合，R. Gompper らの例に見られる特別 の反応操作が必要であった ${ }^{10)}$.

著者らは，この反応の溶媒，塩基，反応条件について 研究を重称, $\mathrm{NaOH}$ や $\mathrm{KOH}$ の濃厚水溶液を塩基に, 水溶媒中でもこの反応はほぼ定量的に進行することを明
$\underset{\mathrm{CH}_{3} \mathrm{~S}}{\mathrm{CH}_{3} \mathrm{~S}}=\mathrm{CO}_{2} \mathrm{CO}_{2} \mathrm{C}_{2} \mathrm{H}_{5}$
らかにした ${ }^{18,19)}$. 中間に得られるジチオ レート（2）は比較的安定な，結晶水をも った形で単離することも可能となり，

Fig. 3 に示すように, 3, 4, 5 類が容易 に合成できた ${ }^{20,21)} .2$ はさらに，そのチ オールの特性を利用し， 6 や 7 へ誘導することができ， 新しく生成した 4 位の水酸基，カルボニル基の反応性を 利用し，8，9 を合成した22).

マロン酸エステルで得られた知見を，ほかの活性メチ レン化合物に適用することで，既知の方法より容易に多

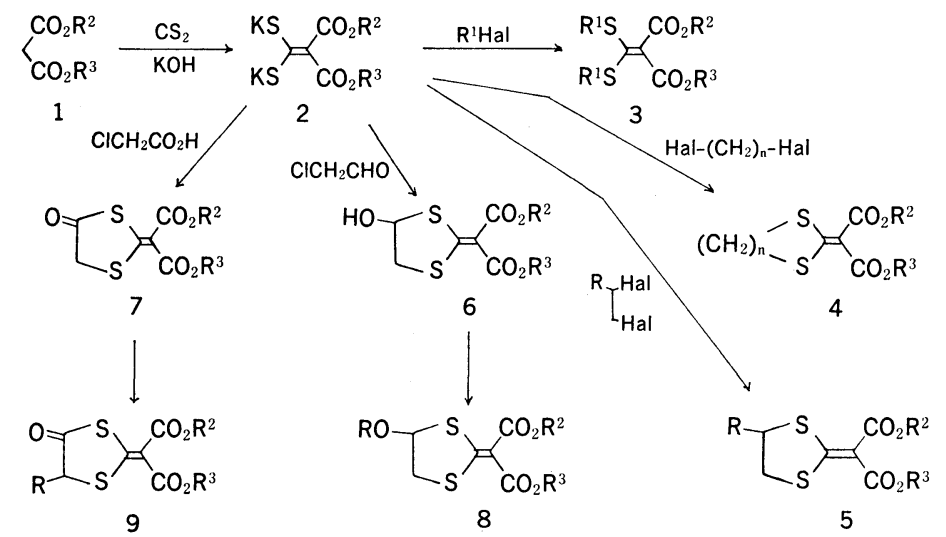

Fig. 3 


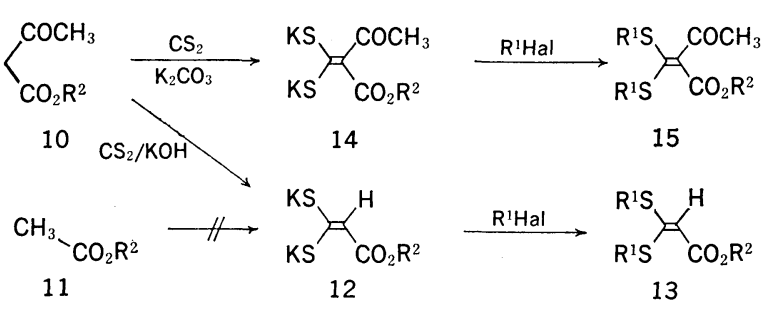

Fig. 4

5 に示すように, 5 を段階的に加水分解し， 16, 17 の酸を得, クロライドにしてから,メルカプタン, アミン等と反応させ合成した ${ }^{20)}$. またジチオラニュ 一ムカチオン（23）を利用する方法も検討し，1,3ジチオラン類の一部を合成した ${ }^{25)}$ (Fig. 6).

ケテン構造をとらないジチオアセタールは，50 還元 ${ }^{24)}$ ，ケトエステル（26）のメルカプタール化で 合成し ${ }^{26)}$, 生物活性に及ぼすケテン構造の意味を考

くの誘導体を合成することが可能となっ た。

しかしアセト酶酸エステルの場合, この 方法では水の存在のため, Fig. 4 に示した ように脱アセチル化を生じ，12 が得られ た.酢酸エステル（11）のメチル基に二硫 化炭素を反応させる試みは，種々の検討に もかかわらず成功しなかったので，乙の結 果は 13 類合成の簡便で優れた方法となっ

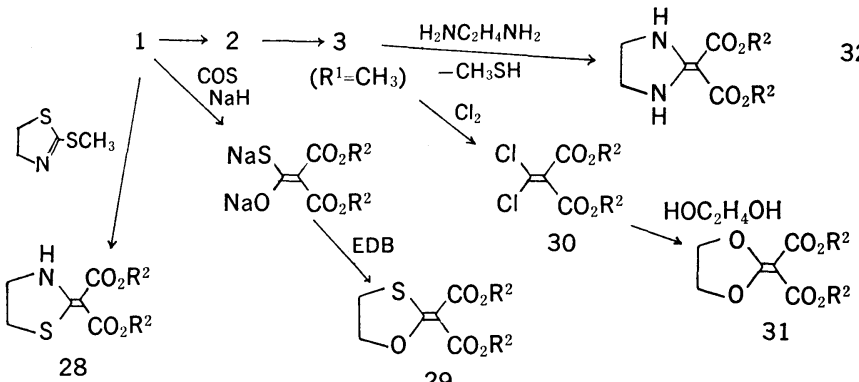
た.

Fig. 8

一方脱アセチルを伴わないで，14を合成する方法を 検討し, DMSO や DMF 中で, 無水の $\mathrm{K}_{2} \mathrm{CO}_{3}$ を用い れば, 高収率で 14 が得られることを見いだし, 関連化 合物 15 類を多数合成した ${ }^{23,24)}$.

後述するように，ジチオラン型化合物に優れたイモチ 察する材料とした (Fig. 7).

ジチオラン環のイオウ原子を, 他のへテロ原子, 酸素 や窒素に置換し，生物活性との関係を知る目的で， Fig. 8 のように, チアゾリジン (28), チオキソラン (29), ジオキソラン $(31)$, イミダゾリジン $(32)$ を合成した ${ }^{24)}$. ケテンジチオアセタールのイオウ原子 1 個を窒素に置 効果が見られたので，この関連化合物のあるものは Fig.

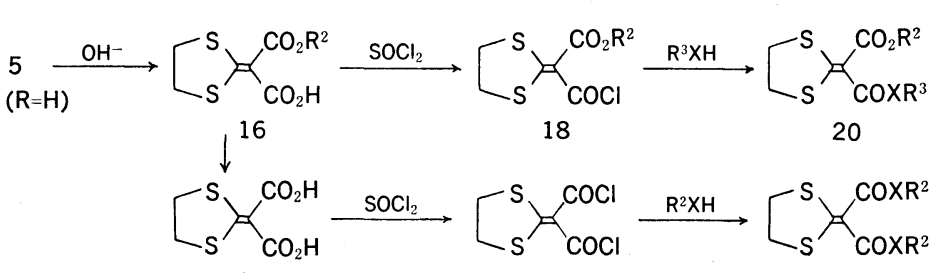

17
21
19

Fig. 5 換したケテン-S, $N$-アセタール (35) の合成法として， $\beta$ 位に電子吸引基を 有する 33 のメチルチオ基とアミンと の求核置換反応を利用する方法 ${ }^{10,27)}$ 少 よく知られている。しかしこの方法で は, 電子吸引基やアミンの種類によっ て合成できる化合物に制限があり，メ

チルチオ基以外のアルキルチオ基での<smiles>S=C1SCCS1</smiles>

22
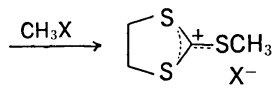

23

Fig. 6 検討はほとえどなされていない，そこで著者らは，活性 メチレン化合物に,イオチオシアナートを反応させ, チオ アミド（34）を得，これを $S$ アルキル化して 36 に導く 方法を検討し，この関連化合物を合成した ${ }^{28,29)}$ (Fig. 9).

以上のように，3a のイモ千活性の発見を契機に，活

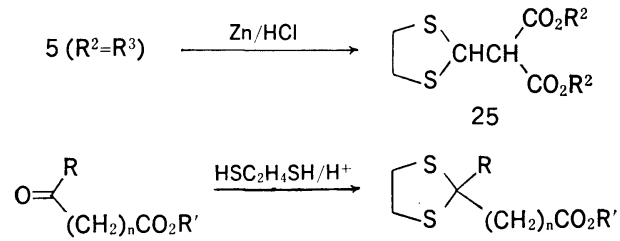

26
27

Fig. 7

32 
性メチレンと二硫化炭素の反応を研究し，ケテンジチオ アセタール類やその関連化合物を合成した。

\section{生 物 活 性}

新農薬創製の第一歩は，生物に対して何らかの活性 （生物活性）をもつ化合物を見つけることであり，生物活 性の的確な評価が新農薬創製の場では最も重要である. 生物活性の検定法として, in vitro で化合物が対象生物 に示す,直接的活性を評価することも重要であるが, 現在 では，作物あるいは土塞を介在させた実験系で，chemical-host-parasite の間の総合的な関係から，作物保護の 観点にたって生物活性を評価しようとする試みも，多く 採用されてきている.

水稲の重要病害イモチ病でも in vitro の抗菌力と実 際の防除効果の不一致が認められて以来 ${ }^{30,31)}$ ，稲体にイ モチ菌を接種, 発病させ, 薬剤の効果を検定するin vivo の試験法がより的確な評価法として多く採用されてい る.非水銀イモチ薬としての, 有機リン剂, 有機塩素剤

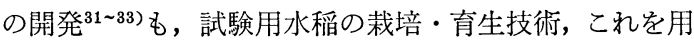
いるイモチ菌の接種, 発病の研究の進歩によって, ポッ ト試験で薬剤の効果が的確に評価できるようになったか らこそ可能であったといえよう.

著者らも，合成化合物はこの方法で，イモチに対する 活性を主体に検定した. 当時, 新しいイモ千薬剤には強 い浸透移行性と効果の持続性がとくに要求されていたの で, ポット試験で治療効果（接種後散布）と予防効果（接 種前散布）を検定してから，効果のみられた化合物につ

Table 1 Rice blast control of

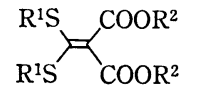

\begin{tabular}{|c|c|c|c|c|c|c|}
\hline \multirow{2}{*}{ No. } & \multirow{2}{*}{$\mathrm{R}^{1}$} & \multirow{2}{*}{$\mathrm{R}^{2}$} & \multicolumn{4}{|c|}{ Rice blast control } \\
\hline & & & $-1^{*}$ & +1 & +6 & systemic \\
\hline $\mathbf{3 a}$ & $\mathrm{CH}_{3}$ & \multirow{4}{*}{$\mathrm{C}_{2} \mathrm{H}_{5}$} & $\mathrm{C}^{* * * *}$ & $\mathrm{D}$ & & $\mathrm{D}$ \\
\hline b & $\mathrm{C}_{2} \mathrm{H}_{5}$ & & B & $\mathrm{D}$ & & $\mathrm{D}$ \\
\hline c & $n-\mathrm{C}_{3} \mathrm{H}_{7}$ & & B & $\mathrm{D}$ & & $\mathrm{D}$ \\
\hline d & $n-\mathrm{C}_{4} \mathrm{H}_{9}$ & & $\mathrm{D}$ & $\mathrm{C}$ & $\mathrm{D}$ & $\mathrm{D}$ \\
\hline $\mathbf{e}$ & $\mathrm{CH}_{3}$ & \multirow{4}{*}{ iso $-\mathrm{C}_{3} \mathrm{H}_{7}$} & A & D & & $\mathrm{D}$ \\
\hline $\mathbf{f}$ & $\mathrm{C}_{2} \mathrm{H}_{5}$ & & $\mathrm{~A}$ & $\mathrm{D}$ & & $\mathrm{D}$ \\
\hline $\mathbf{g}$ & $n-\mathrm{C}_{3} \mathrm{H}_{7}$ & & $\mathrm{D}$ & $\mathrm{D}$ & & \\
\hline h & $n-\mathrm{C}_{4} \mathrm{H}_{9}$ & & $\mathrm{D}$ & $\mathrm{D}$ & & \\
\hline $\begin{array}{r}* \\
* * \\
* * *\end{array}$ & \multicolumn{6}{|c|}{$\begin{array}{l}\text { Degree of rice blast control. A: over } 90 \% \\
\text { control, B: } 80-90 \% \text { control, C: } 60-80 \% \text { con- } \\
\text { trol, D: less than } 60 \% \text { control. }\end{array}$} \\
\hline
\end{tabular}

いては，持続性と浸透移行性を詳しく検討した。このた めに薬剤散布後 6 日目にイモチ菌を接種し，新しく展開 した新葉での効果を見る方法と，水耕試験で薬剤の吸収 移行性を評価する方法を採用した ${ }^{34)}$.

Table 1 に, ケテンジチオアセタール 3 のイモチに 対する効果を示した ${ }^{34)}$. 治療効果の強い化合物 $(\mathbf{3 e}, \mathbf{3 f})$ や，予防効果を示す化合物も見られたが，持続性，浸透 移行性に欠けた. 治療効果 $(-1)$ と化合物の置換基 $\mathrm{R}^{1}$, $\mathrm{R}^{2}$ の総炭素数との関係を図示すれば Fig. 10 が得られ， 効果と炭素数の間にパラボリックな関係が認められた。

3 類の持続性，浸透移行性に劣る点は，これを 1,3 ジチオラン型化合物へ展開することで改善されたが， Table 2 で明らかなように, 環構造をとる化合物の中で ジチオランのみが優れた効果を示すことは興味深い.

環化による化合物の安定化が，生物活性にまで関係し ていることは当然予想されるが，イモ千効果に及ぼす， ジチオランの特異性は, 安定効果だけでは説明できない.

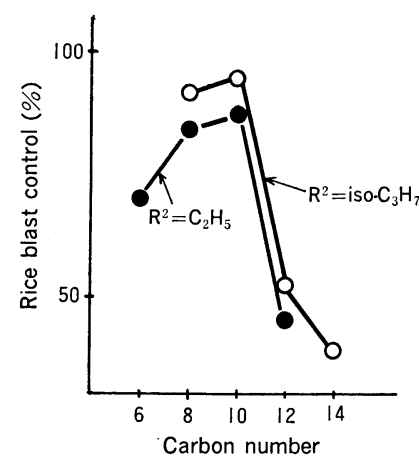

Fig. 10 Relationship between rice blast control of $\left(\mathrm{R}^{1} \mathrm{~S}\right)_{2} \mathrm{C}=\mathrm{C}\left(\mathrm{CO}_{2} \mathrm{R}^{2}\right)_{2}$ and carbon number in $\mathrm{R}^{1}$ and $\mathrm{R}^{2}$.

Table 2 Rice blast control of $\left(\mathrm{CH}_{2}\right)_{\mathrm{n}_{\mathrm{S}}}^{-\mathrm{S}} \mathrm{COOR}_{\mathrm{COOR}^{2}}^{\mathrm{COOR}^{2}}$.

\begin{tabular}{|c|c|c|c|c|c|c|}
\hline \multirow{2}{*}{ No. } & \multirow{2}{*}{$\mathrm{R}^{2}$} & \multirow{2}{*}{$n$} & \multicolumn{4}{|c|}{ Rice blast control } \\
\hline & & & -1 & +1 & +6 & systemic \\
\hline $4 \mathbf{a}$ & \multirow{4}{*}{$\mathrm{C}_{2} \mathrm{H}_{5}$} & 1 & $\mathrm{D}$ & $\mathrm{D}$ & \multirow{4}{*}{$\mathrm{D}$} & \multirow{4}{*}{ A } \\
\hline $5 \mathbf{a}$ & & 2 & A & $\mathrm{C}$ & & \\
\hline $4 b$ & & 3 & $\mathrm{D}$ & $\mathrm{D}$ & & \\
\hline $4 c$ & & 4 & $\mathrm{D}$ & $\mathrm{D}$ & & \\
\hline $4 d$ & \multirow{4}{*}{ iso- $\mathrm{C}_{3} \mathrm{H}_{7}$} & 1 & $\mathrm{D}$ & $\mathrm{D}$ & \multirow{4}{*}{ B } & \multirow{4}{*}{ A } \\
\hline $\mathbf{5 b}$ & & 2 & B & A & & \\
\hline $4 e$ & & 3 & $\mathrm{D}$ & $\mathrm{D}$ & & \\
\hline $4 f$ & & 4 & $\mathrm{D}$ & $\mathrm{D}$ & & \\
\hline
\end{tabular}

Note: Symbols are the same as those in Table 1. 
Table 3 Rice blast control of

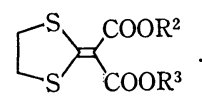

\begin{tabular}{|c|c|c|c|c|c|c|}
\hline \multirow{2}{*}{ No. } & \multirow{2}{*}{$\mathrm{R}^{2}$} & \multirow{2}{*}{$\mathrm{R}^{3}$} & \multicolumn{4}{|c|}{ Rice blast control } \\
\hline & & & -1 & +1 & +6 & systemic \\
\hline $5 c$ & $\mathrm{CH}_{3}$ & $\mathrm{CH}_{3}$ & $\mathrm{D}$ & $\mathrm{D}$ & & $\mathrm{C}$ \\
\hline d & $\mathrm{CH}_{3}$ & $\mathrm{C}_{2} \mathrm{H}_{5}$ & $\mathrm{D}$ & $\mathrm{D}$ & & $\mathrm{C}$ \\
\hline $\mathbf{a}$ & $\mathrm{C}_{2} \mathrm{H}_{5}$ & $\mathrm{C}_{2} \mathrm{H}_{5}$ & $\mathrm{~A}$ & $\mathrm{C}$ & $\mathrm{D}$ & A \\
\hline $\mathbf{e}$ & $\mathrm{C}_{2} \mathrm{H}_{5}$ & iso- $\mathrm{C}_{3} \mathrm{H}_{7}$ & A & A & $\mathrm{B}$ & $\mathrm{A}$ \\
\hline b & iso- $\mathrm{C}_{3} \mathrm{H}_{7}$ & iso- $\mathrm{C}_{3} \mathrm{H}_{7}$ & $\mathrm{~B}$ & A & B & $\mathrm{A}$ \\
\hline $\mathbf{f}$ & $n-\mathrm{C}_{3} \mathrm{H}_{7}$ & $n-\mathrm{C}_{3} \mathrm{H}_{7}$ & $\mathrm{~B}$ & $\mathrm{~A}$ & $\mathrm{D}$ & $\mathrm{C}$ \\
\hline $\mathbf{g}$ & $\mathrm{C}_{2} \mathrm{H}_{5}$ & sec $-\mathrm{C}_{4} \mathrm{H}_{9}$ & A & $\mathrm{A}$ & $\mathrm{B}$ & $\mathrm{B}$ \\
\hline $\mathbf{h}$ & iso- $\mathrm{C}_{3} \mathrm{H}_{7}$ & iso- $\mathrm{C}_{4} \mathrm{H}_{9}$ & $\mathrm{C}$ & A & $\mathrm{B}$ & $\mathrm{B}$ \\
\hline $\mathbf{i}$ & tert- $\mathrm{C}_{4} \mathrm{H}_{9}$ & tert- $\mathrm{C}_{4} \mathrm{H}_{9}$ & $\mathrm{D}$ & $\mathrm{B}$ & $\mathrm{A}$ & $\mathrm{B}$ \\
\hline $\mathbf{j}$ & sec $-\mathrm{C}_{4} \mathrm{H}_{9}$ & sec $-\mathrm{C}_{4} \mathrm{H}_{9}$ & $\mathrm{~B}$ & $\mathrm{~B}$ & $\mathrm{~B}$ & $\mathrm{D}$ \\
\hline $\mathbf{k}$ & iso $-\mathrm{C}_{4} \mathrm{H}_{9}$ & iso- $\mathrm{C}_{4} \mathrm{H}_{9}$ & $\mathrm{~B}$ & $\mathrm{C}$ & $\mathrm{D}$ & $\mathrm{D}$ \\
\hline 1 & $n-\mathrm{C}_{4} \mathrm{H}_{9}$ & $n-\mathrm{C}_{4} \mathrm{H}$ & $\mathrm{D}$ & $\mathrm{D}$ & & \\
\hline m & iso- $\mathrm{C}_{5} \mathrm{H}_{11}$ & iso- $\mathrm{C}_{5} \mathrm{H}_{11}$ & A & $\mathrm{D}$ & & \\
\hline $\mathbf{n}$ & $n-\mathrm{C}_{5} \mathrm{H}_{11}$ & $n-\mathrm{C}_{5} \mathrm{H}_{11}$ & $\mathrm{D}$ & $\mathrm{D}$ & & $\mathrm{D}$ \\
\hline
\end{tabular}

2 個のイオウに挾まれた炭素原子の結合角度が活性発現 の場で重要な意味をもっているのかも知れない34).

5 類のエステルのアルキル基, $\mathrm{R}^{2}, \mathrm{R}^{3}$ と活性の関係 は Table 3 のようになり, $\mathrm{R}^{2}$ と $\mathrm{R}^{3}$ が炭素数 $2 \sim 5$ の アルキル基で, その総炭素数 $4 \sim 8$ の化合物が治療, 予 防，持続性，浸透移行性の点から優れたイモチ病防除効

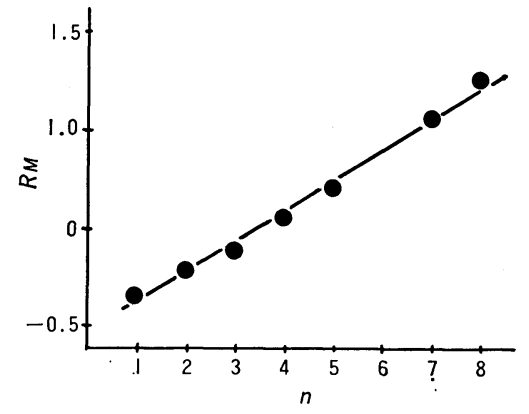

Fig. 11 Relationship between $\mathrm{RM}$ value and car-

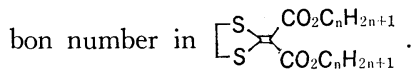

Note: Symbols are the same as those in Table 1.

Table 4 Rice blast control of

\begin{tabular}{|c|c|c|c|c|c|c|c|c|}
\hline \multirow{2}{*}{ No. } & \multirow{2}{*}{$\mathrm{R}^{2}$} & \multirow{2}{*}{$\mathrm{X}$} & \multirow{2}{*}{$\mathrm{R}^{3}$} & \multirow{2}{*}{$\mathrm{Y}$} & \multicolumn{4}{|c|}{ Rice blast control } \\
\hline & & & & & -1 & +1 & +6 & systemic \\
\hline $20 \mathrm{a}$ & $\mathrm{C}_{2} \mathrm{H}_{5}$ & $\mathrm{O}$ & $\mathrm{C}_{2} \mathrm{H}_{5}$ & $S$ & A & $\mathrm{B}$ & $\mathrm{C}$ & $\mathrm{D}$ \\
\hline $\mathbf{b}$ & $\mathrm{C}_{2} \mathrm{H}_{5}$ & $\mathrm{O}$ & iso- $\mathrm{C}_{3} \mathrm{H}_{7}$ & $\mathrm{~S}$ & $\mathrm{D}$ & $\mathrm{A}$ & $\mathrm{C}$ & $\mathrm{D}$ \\
\hline c & $\mathrm{C}_{2} \mathrm{H}_{5}$ & $\mathrm{O}$ & $n-\mathrm{C}_{4} \mathrm{H}_{9}$ & $\mathrm{~S}$ & $\mathrm{C}$ & A & $\mathrm{D}$ & $\mathrm{D}$ \\
\hline d & $\mathrm{C}_{2} \mathrm{H}_{5}$ & $\mathrm{O}$ & $\mathrm{H}$ & $\mathrm{NH}$ & $\mathrm{C}$ & A & $\mathrm{D}$ & $\mathrm{D}$ \\
\hline $\mathbf{e}$ & $\mathrm{C}_{2} \mathrm{H}_{5}$ & $\mathrm{O}$ & $\mathrm{C}_{2} \mathrm{H}_{5}$ & $\mathrm{NH}$ & D & $\mathrm{C}$ & $\mathrm{D}$ & $\mathrm{D}$ \\
\hline f & $\mathrm{C}_{2} \mathrm{H}_{5}$ & $\mathrm{O}$ & iso- $\mathrm{C}_{3} \mathrm{H}_{7}$ & $\mathrm{NH}$ & $\mathrm{D}$ & $\mathrm{B}$ & $\mathrm{D}$ & D \\
\hline $\mathbf{g}$ & $\mathrm{C}_{2} \mathrm{H}_{5}$ & $\mathrm{O}$ & $n-\mathrm{C}_{4} \mathrm{H}_{9}$ & $\mathrm{NH}$ & $\mathrm{D}$ & $\mathrm{D}$ & & \\
\hline h & $\mathrm{C}_{2} \mathrm{H}_{5}$ & $\mathrm{O}$ & $\left(\mathrm{C}_{2} \mathrm{H}_{5}\right)_{2}$ & $\mathrm{~N}$ & $\mathrm{D}$ & $\mathrm{D}$ & & \\
\hline 21a & $\mathrm{C}_{2} \mathrm{H}_{5}$ & $S$ & $\mathrm{C}_{2} \mathrm{H}_{5}$ & $\mathrm{~S}$ & $\mathrm{C}$ & A & $\mathrm{D}$ & $\mathrm{D}$ \\
\hline b & iso- $\mathrm{C}_{3} \mathrm{H}_{7}$ & $\mathrm{~S}$ & iso- $\mathrm{C}_{3} \mathrm{H}_{7}$ & $\mathrm{~S}$ & $\mathrm{C}$ & $\mathrm{C}$ & $\mathrm{D}$ & $\mathrm{D}$ \\
\hline c & $n-\mathrm{C}_{4} \mathrm{H}_{9}$ & $\mathrm{~S}$ & $n-\mathrm{C}_{4} \mathrm{H}_{9}$ & S & $\mathrm{C}$ & $\mathrm{C}$ & $\mathrm{D}$ & $\mathrm{D}$ \\
\hline d & $n-\mathrm{C}_{8} \mathrm{H}_{17}$ & $\mathrm{~S}$ & $n-\mathrm{C}_{8} \mathrm{H}_{17}$ & $\mathrm{~S}$ & $\mathrm{C}$ & $\mathrm{C}$ & $\mathrm{D}$ & $\mathrm{D}$ \\
\hline $\mathbf{e}$ & $\mathrm{C}_{2} \mathrm{H}_{5}$ & $\mathrm{NH}$ & $\mathrm{C}_{2} \mathrm{H}_{5}$ & $\mathrm{NH}$ & $\mathrm{D}$ & $\mathrm{D}$ & & \\
\hline f & iso- $\mathrm{C}_{3} \mathrm{H}_{7}$ & $\mathrm{NH}$ & iso- $\mathrm{C}_{3} \mathrm{H}_{7}$ & $\mathrm{NH}$ & $\mathrm{C}$ & $\mathrm{C}$ & $\mathrm{D}$ & $\mathrm{D}$ \\
\hline g & $n-\mathrm{C}_{4} \mathrm{H}_{9}$ & $\mathrm{NH}$ & $n-\mathrm{C}_{4} \mathrm{H}_{9}$ & $\mathrm{NH}$ & B & $\mathrm{C}$ & D & $\mathrm{D}$ \\
\hline h & $n-\mathrm{C}_{5} \mathrm{H}_{11}$ & $\mathrm{NH}$ & $n-\mathrm{C}_{5} \mathrm{H}_{11}$ & $\mathrm{NH}$ & $\mathrm{D}$ & $\mathrm{B}$ & $\mathrm{D}$ & $\mathrm{D}$ \\
\hline $\mathbf{i}$ & $\left(\mathrm{C}_{2} \mathrm{H}_{5}\right)_{2}$ & $\mathrm{~N}$ & $\left(\mathrm{C}_{2} \mathrm{H}_{5}\right)_{2}$ & $\mathrm{~N}$ & $\mathrm{D}$ & $\mathrm{D}$ & & \\
\hline $\mathbf{j}$ & $\left(\text { iso- } \mathrm{C}_{3} \mathrm{H}_{7}\right)_{2}$ & $\mathrm{~N}$ & $\left(\text { iso }-\mathrm{C}_{3} \mathrm{H}_{7}\right)_{2}$ & $\mathrm{~N}$ & $\mathrm{D}$ & $\mathrm{D}$ & & \\
\hline
\end{tabular}

Note: Symbols are the same as those in Table 1. 
果を示した。

C. B. C. Boyce $~^{35}$ ) は, 化合物の親水, 疎水の程度 を簡便に評価し，生物活性との関係を考察する一方法と して, 逆相薄層クロマトグラフィーより得られる RM 值 の適用を提案している. 著者らもこの方法を応用し， 5 の直鎖アルキルを選び，その RM 值を求め構造との関 係をみた。この結果は Fig. 11 のようになり，炭素数と 疎水性の間に直線関係がみられた。すなわち，5では， $\mathrm{R}^{2}$ と $\mathrm{R}^{3}$ を選ぶことで，その疎水性を任意に調節でき る。そして強い活性を現わすためには，適度な疎水性を 保持することが必要で，これが $\mathrm{R}^{2}$ と $\mathrm{R}^{3}$ は $\mathrm{C}_{2} \sim \mathrm{C}_{5}$ の アルキルで, その総炭素数 $4 \sim 8$ 付近に存在しているこ とが Table 3 よりわかる.

20,21 のように，マロン酸エステルをチオールやアミ ドに変えた化合物の活性の例を Table 4 に示した. 20a は強い活性を示したが，持続性，浸透移行性に欠け，5a には打よばなかった20)。

マロン酸エステル以外の活性メチレンより誘導された ケテンジチオフセタール類のなかでは， $\beta$-ケトエステル 残基をもつものに優れたイモ千病防除効果を示すものが 見られ，Table 5 に示すような構造と活性の関係が得ら れた ${ }^{24)}$. 15b は，固場試験でも $5 \mathbf{b}$ に匹敵する効果を示 し，浸透移行性も優れていた。

ジチオラン環に置換基を導入した化合物の中には，1 モチに強い活性を有するものはなかったが，4位にクロ

Table 5 Rice blast control of

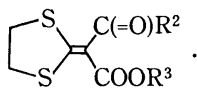

\begin{tabular}{|c|c|c|c|c|c|c|}
\hline \multirow{2}{*}{ No. } & \multirow{2}{*}{$\mathrm{R}^{2}$} & \multirow{2}{*}{$\mathrm{R}^{3}$} & \multicolumn{4}{|c|}{ Rice blast control } \\
\hline & & & -1 & +1 & +6 & $\begin{array}{l}\text { sys- } \\
\text { temic }\end{array}$ \\
\hline $15 \mathrm{a}$ & $\mathrm{CH}_{3}$ & $\mathrm{C}_{2} \mathrm{H}_{5}$ & D & D & & \\
\hline b & $\mathrm{CH}_{3}$ & iso $-\mathrm{C}_{3} \mathrm{H}_{7}$ & $\mathrm{~A}$ & B & $\mathrm{C}$ & A \\
\hline c & $\mathrm{CH}_{3}$ & $n-\mathrm{C}_{4} \mathrm{H}_{9}$ & $\mathrm{~B}$ & $\mathrm{C}$ & D & \\
\hline d & $\mathrm{CH}_{3}$ & iso- $\mathrm{C}_{4} \mathrm{H}_{9}$ & B & D & & \\
\hline $\mathbf{e}$ & $\mathrm{CH}_{3}$ & iso- $\mathrm{C}_{5} \mathrm{H}_{11}$ & B & $\mathrm{D}$ & & \\
\hline f & $\mathrm{CH}_{3}$ & $n-\mathrm{C}_{7} \mathrm{H}_{15}$ & $\mathrm{D}$ & D & & \\
\hline $\mathbf{g}$ & $\mathrm{CH}_{3}$ & $\mathrm{C}_{2} \mathrm{H}_{5} \mathrm{OC}_{2} \mathrm{H}_{4}$ & $\mathrm{D}$ & $\mathrm{D}$ & & \\
\hline h & $\mathrm{C}_{2} \mathrm{H}_{5}$ & $\mathrm{C}_{2} \mathrm{H}_{5}$ & $\mathrm{D}$ & D & D & B \\
\hline $\mathbf{i}$ & $n-\mathrm{C}_{3} \mathrm{H}_{7}$ & $\mathrm{C}_{2} \mathrm{H}_{5}$ & $\mathrm{D}$ & $\mathrm{D}$ & $\mathrm{D}$ & $\mathrm{C}$ \\
\hline $\mathbf{j}$ & $\mathrm{CH}_{2}=\mathrm{CHCH}_{2}$ & $\mathrm{C}_{2} \mathrm{H}_{5}$ & $\mathrm{D}$ & A & $\mathrm{D}$ & $\mathrm{D}$ \\
\hline $\mathbf{k}$ & iso- $\mathrm{C}_{4} \mathrm{H}_{9}$ & $\mathrm{C}_{2} \mathrm{H}_{5}$ & A & B & D & \\
\hline 1 & & $\mathrm{C}_{2} \mathrm{H}_{5}$ & B & D & $\mathrm{D}$ & \\
\hline $\mathbf{m}$ & $-\mathrm{CH}_{2}$ & $\mathrm{C}_{2} \mathrm{H}_{5}$ & D & D & D & $\mathrm{D}$ \\
\hline
\end{tabular}

Note: Symbols are the same as those in Table 1.
ロメチル基を有するジチオラン類のあるものは $(5, \mathrm{R}=$ $\mathrm{CH}_{2} \mathrm{Cl}$ ), 稲モンガレ病に強い活性を示した ${ }^{23)}$.

イオウ原子から $\beta$ 位の塩素原子は活性であることがよ く知られており，4-クロロメチルジチオラン類の稲モン ガレ病に対する強い活性も, この活性塩素に由来してい ることが,この化合物の示す化学的性質より推察された。

Fig. 7 で説明した，二重結合を飽和した化合物，25, 27 はイモチに活性を示さず，二重結合，すなわちケテ ンジチオアセタール構造が活性発現上非常に重要である ことを明らかにした ${ }^{24)}$.

ジチオラン環のイオウを酸素や穻素で置換した化合物 28，29，31，32 (Fig. 8) や，Fig. 9 で説明したケテンー $S, N$-アセタールもイモチに活性を示さない事実等から， 活性発現のためには 2 個のイオウが必須であり，イオウ 原子が生物活性に重要な意味をもっていることがわか る.

以上の結果に基づき，さらにさまざまの実用化の検討 を重ね，最終的にイソプロチオラン $(\mathbf{5 b})$ が新しい，有 機イオウ系の浸透性イモチ薬として選抜され，開発され た。

イソプロチオランの物理化学的諸性質や，本化合物が 示す作用の多面性，安全性等については別に報告したの で36)，本稿では省略したが，この化合物が，水稲の重要 害虫ウンカ類に対して示す作用は，乙れからの新しい作 用物質を開発してゆく上で貴重な示唆を与えてくれたの で簡単に紹介する.

イモチ病防除のためのイソプロチオランの施用が，そ の围場内でのウンカ類の生息密度を低下させ，稲の被害 を著しく軽減させていることが，三宅らによって発見さ

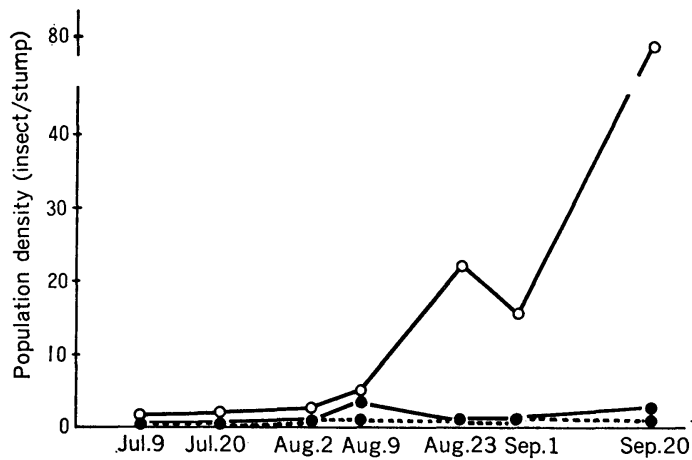

Fig. 12 Effect of Isoprothiolane on the population density of brown planthopper in the field.

$-\mathrm{O}-$ Control, —— Isoprothiolane (Jul. 9 and Aug. 2)*, - - - - Isoprothiolane (Jun. 9 and Aug. 2)

* day of application. 
れた ${ }^{37)}$ (Fig. 12)。この化合物が，リン戍，カーバメー 卜戍が示すような直接的な殺虫力をもたないのに，実際 の圑場でウンカ類をコントロールする現象について種々 の検討がなされた．稲体を通じてウンカ類がこの化合物 と何らかの接触をした結果, 既存の殺虫剤にみられるよ うな中毒症状を示さず死亡し, 死亡虫には, 脱皮不能, 脱皮不全が多く認められ，その他，成虫寿命の短縮，産 卵数の減少等も観察され, これらの結果が総合されて, 昆虫の生存率の低下という形で効果が発現することが明 らかにされた ${ }^{39)}$.この現象を解析するため, あらかじめ イソプロチオランを処理した水稲を用いて，ウンカを飼 育し, 一定期間後のウンカの生存率を無処理稲でのそれ と比較するという新しい方法が考案され, イソプロチオ ラン誘導体や，代謝関連化合物の，ウンカに対する作用 が検討された ${ }^{38)}$ 。この結果とウンカに対する構造と活性 の関倸については，別稿で報告する予定である.

先にも述べたが, chemical-parasite の二者間の直接的 関係で, 生物活性を評価する方法から, chemical-hostparasite の関係を考虑し，作物保護を目的とした新しい 作用物質の評価法の開発が殺虫剤の分野でも, ますます 重要になってくるように思われる.

\section{おわりに}

本稿で述ベたケテンジオアセタール類は, 稲イモチ, モンガレ病に対する活性や，ウンカ類に対する興味ある 作用の他にも，ここでは省略したが，殺草活性を有する 化合物も見いだされており，多様な生物活性が期待でき る興味ある化合物群の一分野である.

末筆ではあるが，ここで述べたケテンジチオアセター ル類の中からイソプロチオランが誕生したのは，これら の化合物の稲イモチ病への活性を, 最初に的確に評価し てくださった生物研究所の方々, イソプロチオランの関 発に携わり，実用性ある農薬にまで育てあげてくださっ た多くの関係者の皆様方, 筆者の研究室でご協力, ご指 導くださった皆様のおかげであり深く感謝する次第であ る.

\section{引用文 献}

1）福永一夫編：農薬ハンドブック，日本植物防疫協 会, p. 349,1976

2）滝田 清・田村浩国：含硫黄化合物の新しい技術 と利用, シーエムシー, p. 145 211，1975

3) T. Tsumura: Jpn Pestic. Inf. 27, 40 (1976)

4) W. O. Foye: J. Chem. Educ. 46, 841 (1969)

5）武島達夫・深田直昭・村岡 亘・宮内啓子：有機 合成化学協会誌 31，808(1973)
6）特公昭 47-34126

7) U.S. Pat. No. 3761596 (1973)

8) U.S. Pat. No. 3586814 (1974)

9) D. Borrman: "Methoden der Organischen Chemie (Houben Weyl)," Georg Thimie Verlag, Stuttgart, Vol. 7/4, p. 404, 1968

10) R. Gompper \& W. Töpfl: Chem. Ber. 95, 2867 (1962)

11) F. C. V. Larsson \& S. O. Lawesson: Tetrahedron 28, 5341 (1972)

12) P. V. Laakso: Suomen Kemisilehti 17B, 27 (1944); Chem. Abs. 41, 95 ${ }^{h}$ (1945)

13) E. Söderbäck: Acta Chem. Scand. 17, 362 (1963)

14) U.S. Pat. No. 2493071 (1950)

15) K. D. Gundermann \& G. Rape: Chem. Ber. 95, 2076 (1962)

16) K. A. Jensen \& L. Henriksen: Acta Chem. Scand. 22, 1107 (1968)

17) L. Dalgaard, H. Kolind-Anderson \& S. O. Lawesson: Tetrahedron 29, 2077 (1973)

18) U.S. Pat. No. 3876663 (1975)

19）谷中国昭・黑野 等：公開公報 49-13174

20） 谷中国昭 - 黑野 等：日本農芸化学会大会講演要 旨, 札幌, p. 18 (1975)

21）谷中国昭・田中博司・平野 彰・黑野 等：公開 公報 $50-24265$

22）谷中国昭・渡辺千可司 - 黒野 等：公開公報 5198247

23）特公昭 50-22092

24）谷中国昭・黑野 等・原 敏彦・村田菊蔵：日本 農薬学会第一回大会講演要旨集, p. 137-a（1975）

25) R. Meyer \& K. Schaefer: J. Prakt. Chem. 26, 279 (1964)

26) U.S. Pat. No. 2839445 (1958)

27）小林五郎・松田芳郎・夏木令子・富永義則：薬学 雑誌 92, 1468（1972）

28) R. N. Hurd \& G. Delamater: Chem. Rev. 61, 45 (1961)

29） 谷中国昭・黑野 等：未発表

30）石山哲爽・佐藤克己：坂本教授還暦記念論文集, 251 (1971)

31）角 博次 - 高日幸義・近藤泰彦：日植病報 $\mathbf{3 0}$, 121 (1965)

32) N. Nanbu: Jpn. Pestic. Inf. 10, 73 (1971)

33) E. Yoshinaga, H. Yamamoto \& Y. Takahashi: ibid. 10, 69 (1971)

34) K. Taninaka, H. Kurono, T. Hara \& K. Murata: J. Pesticide Sci. 1, 115 (1976)

35) C. B. C. Boyce \& B. V. Milborrow: Nature 208, 537 (1965)

36）杉本達芳・荒木不二夫・谷中国昭：第 10 回農薬 科学シンポジウム, 九州大学 p. 13 (1977)

37）三宅利雄・松原秀男：日本応用動物昆虫学会講演 要旨, p. 542 (1975)

38） 特公昭 51-12687

39） 三宅利雄：農薬 22 (2)，11（1975） 